\title{
Inequalities in mortality of infants under one year of age according to foetal causes and maternal age in rural and urban areas in Poland, 2004-2013
}

\author{
Agnieszka Genowska', Magdalenia Zalewska', Jacek Jamiołkowski', Urszula Stepaniak², \\ Andrzej Szpak ${ }^{3}$, Elżbieta Maciorkowska ${ }^{4}$, Jarosław Pinkas ${ }^{5}$ \\ ${ }^{1}$ Department of Public Health, Medical University, Bialystok, Poland \\ ${ }^{2}$ Department of Epidemiology and Population Studies, Jagiellonian University Medical College, Krakow, Poland \\ ${ }^{3}$ Institute of Rural Health, Lublin, Poland \\ ${ }^{4}$ Department of Developmental Medicine and Pediatric Nursing, Medical University, Bialystok, Poland \\ ${ }^{5}$ School of Public Health, Centre of Postgraduate Medical Education, Warsaw, Poland
}

Genowska A, Zalewska M, Jamiołkowski J, Stepaniak U, Szpak A, Maciorkowska E, Pinkas J. Inequalities in mortality of infants under one year of age according to foetal causes and maternal age in rural and urban areas in Poland, 2004-2013. Ann Agric Environ Med. 2016; 23(2): 285-291. doi: 10.5604/12321966.1203892

\section{Abstract}

Introduction. European countries are characterized by low mortality during the infancy period compared to other areas of the world. However, there are significant disparities in the state of infant health which are related to socio-economic conditions and place of residence.

Objective. Analysis of mortality in Poland from foetal and maternal causes (length of gestation, birth weight, maternal age) in the neonatal and post-neonatal period depending on place of residence (rural and urban areas) in 2004-2013.

Materials and method. Data on mortality during the neonatal and infancy period in 2004-2013 was obtained from the Central Statistical Office. Diagnosed cases of deaths in rural and urban areas were analyzed, taking into account the causes of death according to ICD-10, the duration of pregnancy in weeks, birth weight, and maternal age. Trend analysis and comparison of mortality between rural and urban areas were performed using the Poisson regression model.

Results. In rural areas, neonatal and post-neonatal death rates due to congenital malformations were siginificantly higher than in urban areas. The mortality rate was also higher in rural areas in children born to women aged 20-34 years, and children born after 37 weeks gestation with low birth weight. In the cities, higher post-neonatal mortality was due to respiratory diseases, and in children born after 37 weeks gestation to mothers under the age of 20 years. A decrease in the mortality of newborns and infants was observed, but in rural areas neonatal mortality decreased significantly more slowly. Conclusions. The results indicate the need to intensify programmes aimed at improving access to prenatal and maternity care, especially among women in rural areas.

\section{- Key words}

neonatal period, post-neonatal period, congenital malformations, rural area, urban area, mortality trends

\section{Abbreviations}

EU-15 - countries prior to the expansion in May 2004 (Austria, Belgium, Denmark, Finland, France, Germany, Greece, Ireland (Eire), Italy, Luxembourg, Netherlands, Portugal, Spain, Sweden and the United Kingdom); IMR - infant mortality rate; NMR - neonatal mortality rate; PNMR - post-neonatal mortality rate; I.b. - live births; SIDS - Sudden Infant Death Syndrome

\section{INTRODUCTION}

Mortality of the baby in the neonatal and post-neonatal period is an important indicator of the health of the population, and also a useful measure of social and economic development and the quality of care for mother and child $[1,2]$. In Europe since the 70 s, there has been an $80 \%$ reduction in infant mortality rates and the current level of mortality is the lowest in the world [3]. Despite this, there are significant differences in infant mortality rates between countries, ranging from 1.33/1,000 live births (1.b.) in Luxemburg to 9.01/1,000 1.b. in Romania. A less favourable situation is observed in countries with lower economic levels which joined the European Union (EU) after 2003. In these countries the

Address for correspondence: Agnieszka Genowska, Department of Public Health Medical University, Szpitalna 37, 15-295 Bialystok, Poland

E-mail: agnieszka.genowska@umb.edu.pl

Received: 17 November 2015; accepted: 01 March 2016 rate averages 5.43 deaths/1,000 1.b. and this is about $57 \%$ higher than that for the EU-15 (3.46/1,000 1.b.) $[4,5]$. Poland, like most countries in the EU, is characterized by a decline in infant mortality $[5,6]$, and in the period 2004-2013, the coefficient was reduced from $6.80 / 1,000$ to $4.55 / 1,000$ l.b. However, according to the World Health Organization, infant mortality in Poland in 2012 was $17 \%$ higher compared to the average level of the EU [4]. The geographical disparities in the health status of infants are tending to deepen [5] and may be associated with social, economic and environmental factors, health behaviours of pregnant women and access to medical care $[1,7,8,9]$. One of the factors affecting infant mortality may be living in a rural and urban population. Disparities in socio-economic status between rural and urban areas may affect infant health. Moreover, these areas are characterized by dissimilarity in terms of availability of prenatal and obstetric care, education and health behaviour or quality of the environment $[10,11,12,13]$. 
In Poland, dynamic socio-economic and environmental changes have been observed for more than 20 years, with the greatest intensity occurring in rural areas. These changes, similar to those in Western European countries, are based on shrinking of the agricultural sector of the economy and a concomitant expansion of the commercial and service sectors. A significant impetus for these changes was generated by accession to the EU in 2004, which resulted in an improvement in the technical infrastructure and an increase in the provision of social services. At the same time, there was an improvementin the educational and income levels among the populations of the rural areas with a simultaneous decrease in air pollution $[14,10]$.

Socio-economic changes in Poland entailed demographic changes manifested by a decrease in population growth, the shifting age of women giving birth in later years, a decline in births by teens, and a decrease in the number of marriages[15]. Since 2000, a reversal of the direction of migration has been observed, as reflected by a positive migration balance to rural areas surrounding urban metropolises. On the other hand, in peripheral rural areas, there is the phenomenon of an outflow of population with a higher level of education, which has resulted in stagnation and the risk of poverty. The simultaneous occurrence of these two opposing tendencies, in turn, leads to a polarization of the socio-economic development of the villages $[14,16]$. Access to EU funds has also brought an improvement of conditions in the health care infrastructure: however, the majority of health care is still provided in urban centres [10].

Standards of medical procedure in the field of perinatal care for women and newborns have been updated or introduced [17]. The problem is the limited access to obstetrics and gynaecology services, shortage of staff and old generation equipment. Moreover, there are difficulties in transferring pregnant women and newborns to hospitals of higher reference degrees, mainly due to the periodic lack of places in neonatal intensive care units $[18,19]$. These factors may affect regional differences in infant mortality rates between rural and urban areas.

Conducting studies on health inequalities in the population under one year of age is particularly important in countries with weaker socio-economic conditions, including Poland, where the disparities between rural and urban areas are poorly known.

\section{OBJECTIVES}

The aim of the study was to analyze mortality due to foetal and maternal causes (length of gestation, birth weight, maternal age) in the neonatal and post-neonatal period, depending on the place of residence (rural and urban areas) in 2004-2013 in Poland.

\section{MATERIALS AND METHOD}

The analysis was based on information on mortality in the neonatal period and post-neonatal period due to foetal and maternal conditions in the Polish population in 2004-2013. Information for the analysis was obtained from the Central Statistical Office. The study included diagnosed cases of deaths in rural and urban areas, taking into account the causes of neonatal deaths (aged 0-27 days) and post-neonatal deaths (28-365 days) in accordance with ICD-10 [20]. The following diseases were analyzed: infectious and parasitic diseases (A00-B99), respiratory system diseases (J00-J99), perinatal conditions (P00-P96), congenital malformations (Q00-Q99), Sudden Infant Death Syndrome - SIDS (R95) and external causes (V01-Y89). Also analyzed were the diagnosed cases of death in children during neonatal and post-natal periods (aged 0-365 days) by duration of pregnancy in weeks ( $<37$ weeks, $\geq 37$ weeks), birth weight in grams $(<2,500 \mathrm{~g}$, $\geq 2,500 \mathrm{~g}$ ) and maternal age ( $<20$ years, $20-34$ years, $35-39$ years, $\geq 40$ years).

Mortality under one year of age per 1,000 1.b. was also analyzed in both rural and urban areas, divided into neonatal mortality rate (NMR), post-neonatal mortality rate (PNMR) and infant mortality rate in total (IMR).

The existence of disparities in mortality in the population under one year of age was rated depending on where the children lived, and conditions which caused deaths due to diseases of the neonatal and post-neonatal periods, gestational age, birth weight, maternal age (in 2004-2013). The comparisons were made using the non-parametric Wilcoxon test for dependent samples.

To describe trends in mortality in children under one year of age, Generalized Linear Models were used. The presented study used mortality rates resulting from the above factors as dependent variables; therefore, regression models presented in this paper are Poisson models that include the offset variable that allow the size of the exposed populations to be taken into account. The offset variable was defined as the logarithm of the number of live births in a given period in women in total and grouped, according to maternal age, gestational age and birth weight. The models were used to estimate the effect of place of residence and the effect of time (described in the form of a calendar year), as well as the effect of their interaction, which enabled the assessment of trends in mortality separately for rural and urban areas (assessment of whether the slope as a function of time differs significantly from a constant function), and to compare them for parallelism. Results are presented as average annual percent change (AAPC) of mortality per 1,000 live births, including 95\% confidence intervals.

Statistical analyses were performed using IBM ${ }^{\circ}$ SPSS Statistics for Windows, Version 20.0 (IBM Corp. Armonk, NY, USA). All statistical hypotheses were verified at a significance level of 0.05 .

\section{RESULTS}

In 2004-2013 in Poland, 21,355 infant deaths were recorded. In the analyzed period, the average infant mortality rate was higher in urban areas $(58.3 \%$, i.e. 12,454 deaths) than in rural areas $(41.7 \%$, i.e. 8,901 deaths). Both in urban areas and in rural areas neonatal deaths were more frequently observed (70.8\% and $70.7 \%$, respectively) than post-neonatal ones (29.2\% and $29.3 \%$, respectively). The first cause of neonatal mortality were perinatal conditions (mainly due to a preterm birth, intrauterine asphyxia and infections of the perinatal period), which in urban areas were more frequent (66.4\%) compared to rural areas (62.6\%). Congenital malformations, the second leading cause of neonatal deaths, occurred more often in rural areas (32.6\%) than in urban areas $(28.8 \%)$. The 
third reason was SIDS (1.0\% in the cities, in rural areas $0.9 \%)$. In the post-neonatal period, the main causes of death were congenital malformations (rural areas $44.2 \%$ and in urban areas $37.7 \%$ ), perinatal conditions (urban areas $23.3 \%$, rural areas $21.2 \%$ ) and respiratory diseases (urban areas $8.7 \%$, rural areas $6.9 \%$ ). The great majority of deaths occurred in babies born before 37 weeks gestation with low birth weight (less than 2,500 g); the proportions of these deaths were similar in rural and urban areas (91.8\% and 91.7\%). Among children born after 37 weeks gestation with low body weight, a slightly higher percentage occurred in rural areas (23.2\%) than in urban areas (21.4\%).The largest number of deaths was observed among children of mothers in the age group 20-34 years, both in the case of births before 37 weeks (rural areas $74.3 \%, 72.4 \%$ in urban areas) and births after 37 weeks of pregnancy (75.3\% in rural areas, $73.0 \%$ in urban areas).

Total IMR in urban areas in 2004 was 7.14/1,000 1.b.; in 2013 , this dropped by nearly half to $4.34 / 1,000$ l.b. In rural areas in 2004 , the rate was slightly lower than in the urban areas, 6.35/1,000 1.b., and this value dropped to $4.85 / 1,0001$.b. in 2013. It should be emphasized that the level of total IMR at the beginning of the period was higher in urban areas, and since 2010 the situation has been reversed and total IMR in rural areas has been higher than the rate in urban areas.

In the period 2004-2013, the median value of total IMR did not differ significantly between rural and urban areas (5.63/1,000 1.b. vs. 5.57/1,000 l.b.). A statistically significant downward trend in mortality in urban areas $(5.22 \% /$ year, $95 \%$ CI: $4.72,5.71)$ and rural areas $(3.57 \%$ / year, $95 \%$ CI: 2.85 , 4.29) was observed. At the same time, the rate of decline in infant mortality was significantly faster in urban areas than in rural areas $(\mathrm{p}<0.001)$ (Fig. 1A).

NMR due to congenital malformations was significantly higher in rural areas than in urban areas (median: 1.20/1,000 1.b. vs. 1.06/1,000 1.b.) and showed a statistically significant decreasing trend (rural areas 3.65\%/year, urban areas 5.44\%/year). Also, in rural areas NMR mortality rates due to external causes were significantly higher than in urban areas (median: 0.03/1,000 1.b. vs. 0.02/1,000 1.b.), but there was no significant decrease in rates (Tab. 1). Allcause NMR showed a decreasing trend, significantly higher $(\mathrm{p}<0.001)$ in urban areas $(5.63 \% / y e a r)$ compared to rural areas (3.64\%/year) (Fig. 1B). There was also a significant difference $(p=0.015)$ in the NMR downward trend due to perinatal conditions between urban (5.46\%/year) and rural areas (3.40\%/year) (Fig. 1C).

As in the case of NMR, there was a significant difference in PNMR median values between the rural areas $(0.70 / 1,000$ l.b.) and urban areas $(0.62 / 1,000$ l.b.) in terms of congenital malformations. A statistically significant difference in PNMR trends was observed due to congenital malformations $(\mathrm{p}=0.031)$ between rural and urban areas: in urban areas mortality from these causes significantly decreased (2.39\%/year, $\mathrm{p}=0.002)$, while in rural areas the change in mortality was statistically negligible (Tab. 2, Fig. 1D). In urban areas, there were significantly higher PNMR levels than in rural areas due to respiratory diseases (median: 0.14/1,000 1.b. vs. 0.11/1,000 1.b.), and the rates showed no significant downward trends. It was found, however, that both in urban areas and in rural areas there were significant decreasing trends in relation to PNMR: allcause (4.58\%/year and 3.36\%/year, respectively), perinatal conditions (6.35\%/year and 4.38\%/year) and infectious and
Table 1. Neonatal mortality rates by cause and place of residence, and trends ratios in the years 2004-2013 with model-based estimations

\begin{tabular}{|c|c|c|c|}
\hline \multirow{2}{*}{ Causes of death } & Rural areas & Urban areas & \multirow{2}{*}{$p^{*}$} \\
\hline & \multicolumn{2}{|c|}{ Median in 2004-2013 } & \\
\hline All-causes of NMR & 3.93 & 3.99 & 0.878 \\
\hline Perinatal conditions & 2.50 & 2.68 & 0.139 \\
\hline Congenital malformations & 1.20 & 1.06 & 0.007 \\
\hline SIDS & 0.03 & 0.04 & 0.509 \\
\hline Infectious and parasitic diseases & 0.03 & 0.05 & 0.281 \\
\hline External causes & 0.03 & 0.02 & 0.047 \\
\hline \multirow[t]{2}{*}{ Respiratory system } & 0.02 & 0.02 & 0.546 \\
\hline & \multicolumn{2}{|c|}{ AAPC $(95 \% \mathrm{Cl})$} & $p^{* * *}$ \\
\hline All-causes of NMR & $\begin{array}{c}-3.64 \% * * \\
(-4.33,-2.94)\end{array}$ & $\begin{array}{c}-5.63 \%{ }^{* *} \\
(-6.48,-4.76)\end{array}$ & 0.000 \\
\hline Perinatal conditions & $\begin{array}{c}-3.40 \% * * \\
(-4.50,-2.28)\end{array}$ & $\begin{array}{c}-5.46 \%{ }^{* *} \\
(-6.69,-4.22)\end{array}$ & 0.015 \\
\hline Congenital malformations & $\begin{array}{c}-3.65 \%{ }^{* *} \\
(-5.24,-2.04) \\
\end{array}$ & $\begin{array}{c}-5.44 \%{ }^{* *} \\
(-6.57,-4.30) \\
\end{array}$ & 0.073 \\
\hline SIDS & $\begin{array}{c}-4.78 \% \\
(-10.30,1.07)\end{array}$ & $\begin{array}{c}0.28 \% \\
(-2.13,2.75) \\
\end{array}$ & 0.115 \\
\hline Infectious and parasitic diseases & $\begin{array}{c}-10.13 \% \\
(-18.73,0.73)\end{array}$ & $\begin{array}{c}-9.59 \% \\
(-18.61,0.43)\end{array}$ & 0.936 \\
\hline External causes & $\begin{array}{c}-1.98 \% \\
(-6.24,2.47)\end{array}$ & $\begin{array}{c}-7.13 \% \\
(-13.82,0.08)\end{array}$ & 0.224 \\
\hline Respiratory system & $\begin{array}{c}-3.28 \% \\
(-9.47,3.33)\end{array}$ & $\begin{array}{c}-2.01 \% \\
(-4.59,0.64)\end{array}$ & 0.720 \\
\hline
\end{tabular}

Rate per 1,000 live births: AAPC - average annual percentage change; $\mathrm{Cl}$ - confidence interval; * - Wilcoxon matched pairs test; ** - Statistically significant trend at $\mathrm{p}<0.05$; *** - Wald test for the significance of differences trends

Table 2. Post-neonatal mortality rates by cause and place of residence, and trends ratios in 2004-2013 with model-based estimations

\begin{tabular}{|c|c|c|c|}
\hline \multirow{2}{*}{ Causes of death } & Rural areas & Urban areas & \multirow{2}{*}{$p^{*}$} \\
\hline & \multicolumn{2}{|c|}{ Median in 2004-2013 } & \\
\hline All-causes of PNMR & 1.59 & 1.57 & 0.959 \\
\hline Congenital malformations & 0.70 & 0.62 & 0.009 \\
\hline Perinatal conditions & 0.37 & 0.35 & 0.114 \\
\hline Respiratory system & 0.11 & 0.14 & 0.031 \\
\hline SIDS & 0.10 & 0.12 & 0.141 \\
\hline External causes & 0.07 & 0.08 & 0.259 \\
\hline \multirow[t]{2}{*}{ Infectious and parasitic diseases } & 0.07 & 0.07 & 0.858 \\
\hline & \multicolumn{2}{|c|}{ AAPC $(95 \% \mathrm{Cl})$} & $p^{* * *}$ \\
\hline All-causes of PNMR & $\begin{array}{c}-3.36 \%{ }^{* *} \\
(-4.62,-2.08)\end{array}$ & $\begin{array}{c}-4.58 \% * * \\
(-5.91,-3.22)\end{array}$ & 0.196 \\
\hline Congenital malformations & $\begin{array}{c}0.17 \% \\
(-1.63,2.00) \\
\end{array}$ & $\begin{array}{c}-2.39 \% * * \\
(-3.86,-0.90)\end{array}$ & 0.031 \\
\hline Perinatal conditions & $\begin{array}{c}-4.38 \% * * \\
(-6.56,-2.15) \\
\end{array}$ & $\begin{array}{c}-6.35 \% * * \\
(-8.04,-4.63) \\
\end{array}$ & 0.164 \\
\hline Respiratory system & $\begin{array}{c}-3.28 \% \\
(-9.47,3.33) \\
\end{array}$ & $\begin{array}{c}-2.01 \% \\
(-4.59,0.64) \\
\end{array}$ & 0.720 \\
\hline SIDS & $\begin{array}{c}-6.63 \% * * \\
(-10.15,-2.29) \\
\end{array}$ & $\begin{array}{c}-2.04 \% \\
(-6.86,3.04)\end{array}$ & 0.137 \\
\hline External causes & $\begin{array}{c}-8.39 \% * * \\
(-12.47,-4.11)\end{array}$ & $\begin{array}{c}-3.85 \% \\
(-8.13,0.63) \\
\end{array}$ & 0.141 \\
\hline Infectious and parasitic diseases & $\begin{array}{c}-16.13 \% \%^{* *} \\
(-21.21,-10.73)\end{array}$ & $\begin{array}{c}-10.97 \% * * \\
(-15.49,-6.00)\end{array}$ & 0.146 \\
\hline
\end{tabular}

Rate per 1,000 live births: AAPC - average annual percentage change; $\mathrm{Cl}$ - confidence interval; ${ }^{*}$ - Wilcoxon matched pairs test; ${ }^{* *}-$ Statistically significant trend at $\mathrm{p}<0.05$; *** - Wald test for the significance of differences trends. 

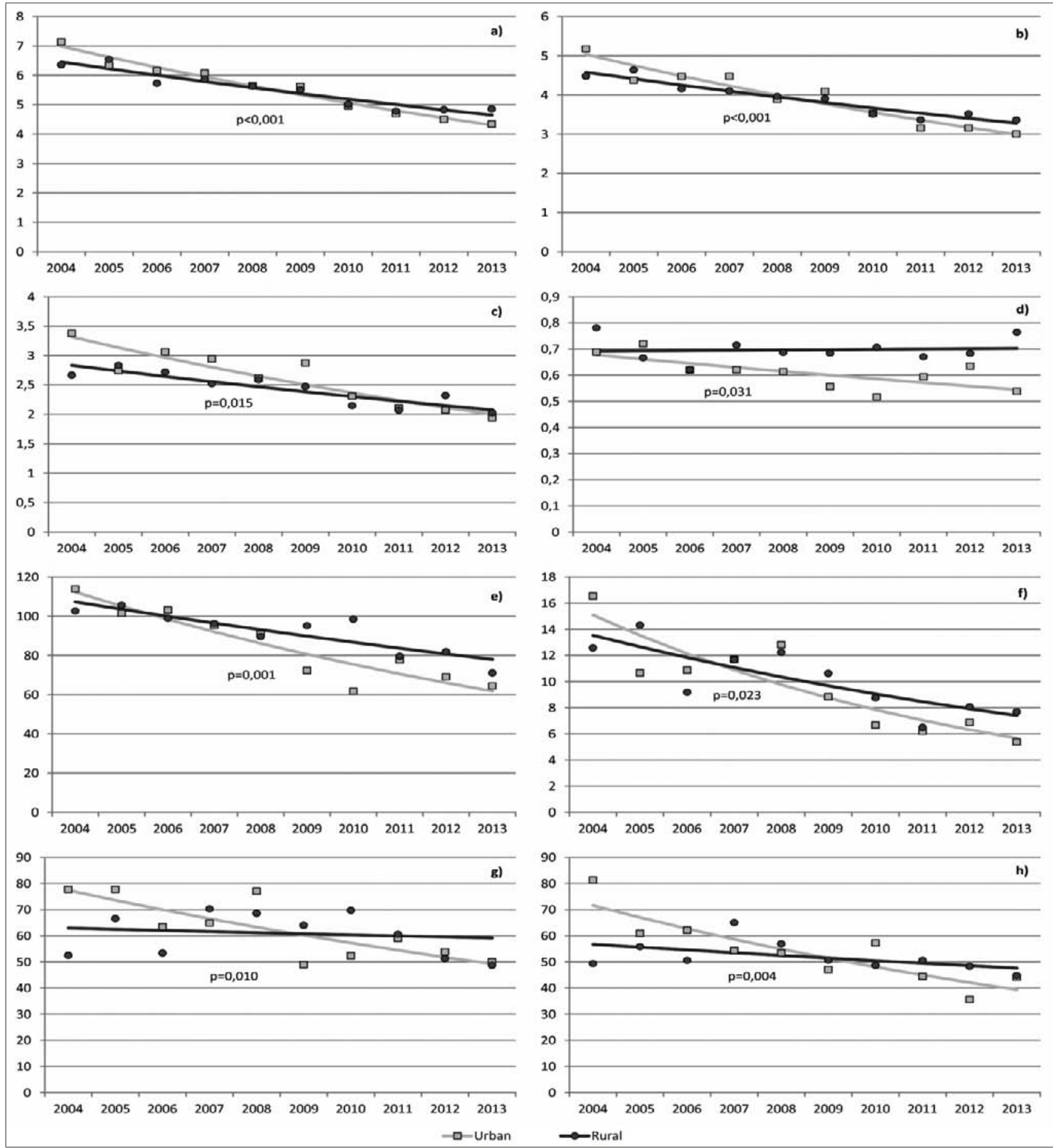

$\mathrm{p}$ - Wald test for diffrences in trends

Figure 1. Trends of infant mortality rates (per 1,000 live births) by place of residence in Poland, 2004-2013 with model-based estimations.

(a) Total infant mortality

(b) Neonatal mortality from all-causes

(c) Neonatal mortality due to perinatal conditions

(d) Post-neonatal mortality due to congenital malformations

(e) Total infant mortality of children born before 37 weeks of pregnancy with a birth weight less than $2,500 \mathrm{~g}$

(f) Total infant mortality of children born before 37 weeks of pregnancy with a birth weight more than $2,500 \mathrm{~g}$

(g) Total infant mortality of children born before 37 weeks of pregnancy in mothers below 20 years old

(h) Total infant mortality of children born before 37 weeks of pregnancy in mothers aged 35-39 years old

parasitic diseases (10.97\%/year and $16.13 \%$ /year). A significant downward trend in PNMR also appeared in rural areas in the case of external causes (8.39\%/year) and SIDS (6.63\%/ year) (Tab. 2).

Considering birth weight, significantly higher levels of total IMR for those born with low birth weight (less than
$2,500 \mathrm{~g}$ ) after 37 weeks of pregnancy were recorded in rural areas (21.84/1,000 l.b.) than in urban areas (17.28/1,000 1.b.). Among children under one year of age born before 37 weeks of pregnancy, significant changes in mortality were observed (Tab. 3). The mortality rate of children born before 37 weeks of pregnancy with low birth weight (less than 2,500 g) showed 
a decreasing trend, significantly higher $(\mathrm{p}=0.001)$ in urban areas $(6.43 \% /$ year), compared to rural areas (3.48\%/year) (Fig. $1 \mathrm{E})$. Downward trends in the mortality rate of babies born before 37 weeks weighing more than $2,500 \mathrm{~g}$ were significantly different $(\mathrm{p}=0.023)$ between urban areas $(10.32 \% /$ year $)$ and rural areas (6.48\%/year) (Fig.1F). Among children under one year of age born after 37 weeks of pregnancy weighing more than $2,500 \mathrm{~g}$, a significant reduction in mortality was noted in urban areas (3.26\%/year) and rural areas (2.91\%/year).

The mortality rate for children born prematurely, i.e. aged less than 37 weeks of pregnancy to mothers aged 20-34, was significantly higher in rural areas than in urban areas (median: 50.71/1,000 1.b. vs. $48.47 / 1,000$ l.b.). In the other age groups, there was no significant difference in the level of mortality. Among the mothers in the age group below 20 years of age and over 40 years of age, mortality significantly decreased in urban areas (4.90\%/year and 5.39\%/year); in rural areas the trend was negligible. Both in urban areas and in rural areas the trends in mortality significantly decreased in mothers in the age group 20-34 years (4.76\%/year and $3.62 \% / y e a r$, respectively), and in the age group 35-39 years (6.42\%/year and 1.93\%.year, respectively). There were significant differences between urban areas and rural areas in the mortality trends in children born prematurely to juvenile mothers in the age group below 20 years of age $(\mathrm{p}=0.010)$ and in the age group 35-39 years ( $\mathrm{p}=0.004)$ (Tab. 4 , Fig. 1 and $1 \mathrm{H}$ ).

The mortality rate for children born after 37 weeks of pregnancy to adolescent mothers was significantly higher in urban areas than in rural areas (median: 3.03/1,000 1.b. vs. $2.28 / 1,000$ l.b.). However, among mothers aged $20-34$ years, a higher mortality of children under one year of age was found in rural areas compared to urban areas (median: 1.90/1,000 l.b. vs. 1.71/1,000 l.b.). For mothers aged over 35, there was no difference between urban areas and rural areas in the mortality of children under one year of age. Statistically significant decreasing trends were found among mothers aged 35-39 years in urban areas (4.82\%/year) and rural areas (3.60\%/year), and in urban areas in the age group 20-34 (1.97\%/year) and the age group over 40 years old (5.73\%/year) (Tab. 4$)$.

\section{DISCUSSION}

The presented study demonstrated that there are inequalities between rural and urban areas in terms of giving birth, as manifested by higher mortality for rural children with congenital malformations, who were born during the neoand post-neonatal period by women aged 20-34, as well as children with low birth weight born after the $37^{\text {th }}$ week of pregnancy. However, in the cities, increased mortality due to respiratory diseases was observed in the postneonatal period, as well as among children who were born to adolescent mothers after the $37^{\text {th }}$ week of pregnancy. Based on the obtained results, it can be assumed that the higher mortality observed in rural areas results from the occurrence of specific factors distinguishing the rural population from the urban population. Worse birth outcomes in rural areas are confirmed by studies conducted in other countries [21, 12, 22].

Congenital malformations in the neonatal and postneonatal period posing higher risk of mortality in rural areas in comparison to cities, are confirmed by other authors [23]. The causes of most congenital malformations are not yet known; however, it is likely that their risk factors are the
Table 3. Total infant mortality rate by birth weight, gestational age and place of residence, and trends in rates in 2004-2013 with model-based estimations

\begin{tabular}{|c|c|c|c|c|c|c|}
\hline \multirow{3}{*}{$\begin{array}{l}\text { Birth } \\
\text { weight }\end{array}$} & \multicolumn{3}{|c|}{$\begin{array}{c}\text { Duration of pregnancy } \\
<37 \text { weeks }\end{array}$} & \multicolumn{3}{|c|}{$\begin{array}{c}\text { Duration of pregnancy } \\
\quad \geq 37 \text { weeks }\end{array}$} \\
\hline & $\begin{array}{l}\text { Rural } \\
\text { areas }\end{array}$ & $\begin{array}{l}\text { Urban } \\
\text { areas }\end{array}$ & & $\begin{array}{l}\text { Rural } \\
\text { areas }\end{array}$ & $\begin{array}{c}\text { Urban } \\
\text { areas }\end{array}$ & \\
\hline & \multicolumn{2}{|c|}{$\begin{array}{c}\text { Median in } \\
2004-2013\end{array}$} & $p^{*}$ & \multicolumn{2}{|c|}{$\begin{array}{c}\text { Median in } \\
2004-2013\end{array}$} & $p^{*}$ \\
\hline$<2500 \mathrm{~g}$ & 95.65 & 84.31 & 0.169 & 21.84 & 17.28 & 0.013 \\
\hline \multirow[t]{2}{*}{$\geq 2500 \mathrm{~g}$} & 9.90 & 9.75 & 0.386 & 1.64 & 1.61 & 0.059 \\
\hline & \multicolumn{2}{|c|}{ AAPC $(95 \% \mathrm{Cl})$} & $p^{* * *}$ & \multicolumn{2}{|c|}{ AAPC $(95 \% \mathrm{Cl})$} & $p^{* * *}$ \\
\hline$<2500 \mathrm{~g}$ & $\begin{array}{c}-3.48 \% \text { ** } \\
(-4.65 \\
-2.30)\end{array}$ & $\begin{array}{c}-6.43 \% \text { ** } \\
(-7.60 \\
-5.24)\end{array}$ & 0.001 & $\begin{array}{c}2.10 \% \\
(-2.03 \\
6.39)\end{array}$ & $\begin{array}{c}-2.11 \% \\
(-5.48 \\
1.37)\end{array}$ & 0.127 \\
\hline$\geq 2500 \mathrm{~g}$ & $\begin{array}{c}-6.48 \% * * \\
(-8.66 \\
-4.25)\end{array}$ & $\begin{array}{c}-10.32 \%{ }^{* *} \\
(-12.73 \\
-7.84)\end{array}$ & 0.023 & $\begin{array}{c}-2.91 \% \text { ** } \\
(-4.25 \\
-1.56)\end{array}$ & $\begin{array}{c}-3.26 \% \text { ** } \\
(-3.78 \\
-2.74)\end{array}$ & 0.638 \\
\hline
\end{tabular}

Rate per 1,000 live births: AAPC - average annual percentage change; $\mathrm{Cl}$ - confidence interval; * - Wilcoxon matched pairs test; ** - Statistically significant trend at $\mathrm{p}<0.05 ;{ }^{* * *}$ - Wald test for significance of differences trends.

Table 4. Total infant mortality rate by maternal age, gestational age and place of residence, and trends in rates in 2004-2013 with model-based estimations

\begin{tabular}{|c|c|c|c|c|c|c|}
\hline \multirow{3}{*}{$\begin{array}{l}\text { Maternal } \\
\text { age }\end{array}$} & \multicolumn{3}{|c|}{$\begin{array}{l}\text { Duration of pregnancy } \\
<37 \text { weeks }\end{array}$} & \multicolumn{3}{|c|}{$\begin{array}{c}\text { Duration of pregnancy } \\
\geq 37 \text { weeks }\end{array}$} \\
\hline & $\begin{array}{l}\text { Rural } \\
\text { areas }\end{array}$ & $\begin{array}{l}\text { Urban } \\
\text { areas }\end{array}$ & & $\begin{array}{l}\text { Rural } \\
\text { areas }\end{array}$ & $\begin{array}{l}\text { Urban } \\
\text { areas }\end{array}$ & \\
\hline & \multicolumn{2}{|c|}{$\begin{array}{l}\text { Median in } \\
\text { 2004-2013 }\end{array}$} & $p^{*}$ & \multicolumn{2}{|c|}{$\begin{array}{l}\text { Median in } \\
2004-2013\end{array}$} & $p^{*}$ \\
\hline$<20$ years & 62.27 & 61.14 & 0.646 & 2.28 & 3.03 & 0.013 \\
\hline $20-34$ years & 50.71 & 48.47 & 0.037 & 1.90 & 1.71 & 0.005 \\
\hline $35-39$ years & 50.58 & 53.83 & 0.959 & 2.45 & 2.04 & 0.139 \\
\hline \multirow[t]{2}{*}{$\geq 40$ years } & 53.23 & 64.11 & 0.646 & 3.89 & 3.29 & 0.575 \\
\hline & \multicolumn{2}{|c|}{ AAPC $(95 \% \mathrm{CI})$} & $p^{* * *}$ & \multicolumn{2}{|c|}{ AAPC $(95 \% \mathrm{Cl})$} & $p^{* * *}$ \\
\hline$<20$ years & $\begin{array}{c}-0.69 \% \\
(-3.70 \\
2.42)\end{array}$ & $\begin{array}{c}-4.90 \% * * \\
(-6.03 \\
-3.75)\end{array}$ & 0.010 & $\begin{array}{c}0.28 \% \\
(-3.59 \\
4.32)\end{array}$ & $\begin{array}{c}0.02 \% \\
(-4.79 \\
5.07)\end{array}$ & 0.935 \\
\hline $20-34$ years & $\begin{array}{c}-3.62 \% \text { ** } \\
(-4.75 \\
-2.48)\end{array}$ & $\begin{array}{c}-4.76 \% * * \\
(-5.56 \\
-3.95)\end{array}$ & 0.111 & $\begin{array}{c}-1.31 \% \\
(-3.14 \\
0.55)\end{array}$ & $\begin{array}{c}-1.97 \% * * \\
(-3.04 \\
-0.89)\end{array}$ & 0.546 \\
\hline $35-39$ years & $\begin{array}{c}-1.93 \% \text { ** } \\
(-3.67 \\
-0.16)\end{array}$ & $\begin{array}{c}-6.42 \% * * \\
(-8.82 \\
-3.97)\end{array}$ & 0.004 & $\begin{array}{c}-3.60 \% \text { ** } \\
(-5.93 \\
-1.22)\end{array}$ & $\begin{array}{c}-4.82 \% * * \\
(-7.76 \\
-1.78)\end{array}$ & 0.532 \\
\hline$\geq 40$ years & $\begin{array}{c}0.61 \% \\
(-3.61 \\
5.02)\end{array}$ & $\begin{array}{c}-5.39 \% * * \\
(-9.53 \\
-1.05)\end{array}$ & 0.052 & $\begin{array}{c}-2.32 \% \\
(-5.20 \\
0.64)\end{array}$ & $\begin{array}{c}-5.73 \% * * \\
(-10.12 \\
-1.12)\end{array}$ & 0.217 \\
\hline
\end{tabular}

Rate per 1,000 live births: AAPC - average annual percentage change; $\mathrm{Cl}$ - confidence interval; * - Wilcoxon matched pairs test; ${ }^{* *}$ - Statistically significant trend at $\mathrm{p}<0.05$; $* * *$ - Wald test for significance of differences trends.

$p$ - Wald test for diffrences in trends.

limited access to prenatal care [24], occupational exposure to pesticides $[25,26]$ and low socio-economic status [27]. These factors are far more common in rural areas and may be associated with higher infant mortality. In the current study, a particularly alarming result we obtained demonstrating a slower pace of decline in post-neonatal mortality due to congenital malformations in rural areas.

In Poland between 2006 and 2008, standard procedures were developed for intrauterine foetal therapy and a training education programme also introduced which allowed doctors from smaller centers to provide and ensure specialist care for 
pregnant women with specific congenital malformations and diseases of the foetus. However, there are difficulties in access to health services in the area of foetal therapy, which is related to limited possibilities of using modern endoscopic methods due to financial constraints and the limited experience of personnel in this field [28].

Existing impediments in terms of access to obstetric and foetal diagnostics in rural areas may be a determining factor when considering the observed difference in the dynamics of post-neonatal mortality trends due to congenital malformations between rural and urban areas (Fig. 1D). Unfavourable birth outcomes may also be promoted by decreased health awareness among women with lower levels of education; they also more often have an unfavourable economic situation, which may be an additional cause for the limited use of preventive and specialist care [29].

Moreover, in rural areas, in comparison to urban ones, higher infant mortality was observed among those born to women aged $20-34$, both before the $37^{\text {th }}$ and after the $37^{\text {th }}$ week of pregnancy, as well as those born after the $37^{\text {th }}$ week of pregnancy with low birth weight. This result can be explained by limitations in the availability of health care associated with a less developed infrastructure and the insufficient employment of medical staff, including gynaecologists and obstetricians in rural areas [30]. This leads to prolonged waiting time, decreased possibility of prevention and adequate prenatal care. These factors may affect patterns of health care use by pregnant women, which poses a risk to the development of the foetus [12].

A significant barrier may be the result of less accessible public transport which prevents moving to larger urban centres [11]. The low socio-economic status of rural women may indirectly contribute to the emergence of adverse exposure to psychosocial stress [30], or occupational exposure to physical activity [11], or chemicals [31] and inadequate nutrition [32] associated with the development of the foetus and low birth weight, which may be associated with worse birth outcomes.

The results obtained show that the urban environment is a risk factor for: 1) higher mortality of children who were born to adolescent mothers after the $37^{\text {th }}$ week of pregnancy, and 2) higher post-neonatal mortality due to respiratory diseases. High-risk pregnancies among teenagers are associated with late obstetric care and fewer visits, and the incidence of complications and foetal hypotrophy [33]. Adolescent mothers often come from dysfunctional families with a low socioeconomic status, are more often unmarried, emotionally immature, and also adopt risky health behaviours [34].

Many studies indicate $[35,23,30]$ that worse birth outcomes are often found in the deprived neighbourhoods of urban areas, in which numbers of unfavourable factors (unemployment, insecurity, pollution) are accumulated. Moreover, in comparison to rural areas, pregnant women in cities more often smoke tobacco and consume alcohol, which negatively affect foetal development [36]. Other authors confirm that deaths due to respiratory diseases occur with uneducated, unmarried mothers, and among women who smoke during pregnancy $[37,38]$.

In the presented study it was found that despite the presence of a favourable decreasing trend in infant mortality, in rural areas a significantly decreased overall infant mortality was observed, along with neonatal mortality due to perinatal conditions, as well as mortality of children born before the $37^{\text {th }}$ week of pregnancy when the mother's age was under 20 and between 35 - 39. In all these cases, the trend line in the country crossed the trend line in the cities, and the points of intersection of the mortality rate estimates were higher in rural areas. This result may indicate a changing way of life in rural areas, which is associated with an inflow of urban population aged 25-44 with secondary and higher education to rural areas located around cities. This population chooses the village as a convenient place to live; however, they are professionally still associated with the city. This entails the conforming of the rural population to the patterns observed in the cities (women are older when they decide to have a child, an increase in the number of divorces) and increases in the distance to health care facilities $[10,16]$. In the country, these factors may be associated with increased mortality rates for children under one year of age.

The results show that the rural environment requires intensified prevention and treatment in obstetrics and gynaecology. The experience of highly-developed countries demonstrates that reduction of mortality in the youngest population is possible through the implementation of intervention programmes targeted at risk groups, particularly those with lower education $[39,40]$. These actions should include care before and during pregnancy, as well as the reduction of post-partum complications and appropriate control over maternal and child health. The aim should be towards integrated efforts of the health care system, public health and social institutions for the detection of birth defects and preventing low birth weight. It is very important that health benefits resulting from support given at an early life stage are apparent in the later stages. These actions might also have long-term effects on the growth of human capital and economic development.

Limitations and strengths of the study. It is recognized that this study has several limitations. Firstly, the routine system for reporting mortality data does not include information about disease states of mother, health care served, education, profession, or income. In addition, there is no information about lifestyle, such as diet, or tobacco and alcohol consumption in pregnant women. The study was of a descriptive character in which it was not possible to determine the precise socio-economic causes of mortality of children under one year of age in rural and urban areas. Nevertheless, this is an interesting topic for further studies among pregnant women and those who are about to give birth. Secondly, mortality data are collected according to the place of death, which may result in an under-estimation in the event pregnant women change their place of residence. The influence of this error, however, is rather small [26].

This is the first study which demonstrates the differences between rural and urban areas in terms of the mortality of children under one year of age with regard to causes of deaths, length of gestation, birth weight and maternal age in Poland. In the study, complete mortality data based on information from the cards of deaths death certificates at the national level were used. In addition, data were analyzed over a 10-year period using the Poisson model which takes into account the interaction between time and place of residence, enabling estimation of the morality trends as well as the differences in their dynamics between rural and urban areas, which have not been previously studied. The current study, therefore, is an important source of information on which the direction of future prevention activities may be determined. 


\section{CONCLUSIONS}

There are disparities in terms of birth rates between women living in rural and urban areas which are associated with causes of death, date of birth, birth weight and maternal age. Disparities in mortality due to congenital malformations and low birth weight are the key for the implementation of intervention in terms of public health aimed at improving the health status of children under the first year of age. The results indicate the need to intensify activities aimed at improving access to prenatal and maternity care, especially among women in rural areas. Regular medical care before and during pregnancy, and continuity of care in terms of maternal and child health can promote early detection of high risk of unfavourable birth outcomes.

\section{REFERENCES}

1. Kim D, Saada A. The social determinants of infant mortality and birth outcomes in Western developed nations: a cross-country systematic review. Int J Environ Res Public Health. 2013; 10(6): 2296-2335.

2. Mishina H, Hilton JF, Takayama JI. Trends and variations in infant mortality among 47 prefectures in Japan. J Eval Clin Pract. 2013; 19(5): 849-854.

3. Organization for Economic Co-Operation and Development: Health at a Glance: Europe 2014. OECD, Paris 2014.

4. World Health Organization. Health for All Database (HFA-DB). http:// data.euro.who.int/hfadb (access: 2015.10.09)

5. Marmot M. Health inequalities in the EU - Final report of a consortium. European Union 2013.

6. EURO-PERISTAT: European Perinatal Health Report. The health and care of pregnant women and babies in Europe in 2010. http://www. europeristat.com/images/doc/Peristat\%202013\%20V2.pdf (access: 2015.10.09)

7. Padilla CM, Deguen S, Lalloue B, Blanchard O, Beaugard C, Troude $\mathrm{F}$, et al. Cluster analysis of social and environment inequalities of infant mortality. A spatial study in small areas revealed by local disease mapping in France. Sci Total Environ. 2013; 454-455: 433-441.

8. Kihal-Talantikite W, Padilla C, Lalloue B., Rougier C, Defrance J, Zmirou-Navier D, et al. An explanatory spatial analysis to assess the relationship between deprivation, noise and infant mortality: an ecological study. Environ Health. 2013; 12: 109. doi: 10.1186/1476-069X12-109.

9. World Health Organization: European strategic approach for making pregnancy safer: Improving maternal and perinatal health. WHO, Copenhagen 2008.

10. Główny Urząd Statystyczny: Obszary wiejskie. Powszechny Spis Rolny. GUS, Olsztyn 2013.

11. Alexy B, Nichols B, Heverly M, Garzon L. Prenatal factors and birth outcomes in the public health service: a rural/urban comparison. Res Nurs Health. 1997; 20(1): 61-70.

12. Hillemeier M, Weisman C, Chase G, Dyer A. Individual and community predictors of preterm birth and low birthweight along the rural - urban continuum an central Pennsylvania. J Rural Health 2007; 23(1): 42-48.

13. Dadvand P, Sunyer J, Basagaña X, Ballester F, Lertxundi A, FernándezSomoano A, et al. Surrounding greenness and pregnancy outcomes in four Spanish birth cohorts. Environ Health Perspect. 2012; 120(10): 1481-1487.

14. Halamska M. Transformacja wsi 1989-2009: zmienny rytm modernizacji. Stud Lok Region. 2011; 44(3): 5-25.

15. Rządowa Rada Ludnościowa: Sytuacja demograficzna Polski, raport 2013-2014. RRL, Warszawa 2014.

16. Dziekoński O, Wóycicka I, Klimczak M. Polska wieś 2012. Potencjał obszarów wiejskich szansą rozwoju. Warszawa, Kancelaria Prezydenta Rzeczypospolitej Polskiej 2013.

17. Rozporządzenie Ministra Zdrowia z dnia 20 września 2012 r. w sprawie standardów postępowania medycznego przy udzielaniu świadczeń zdrowotnych z zakresu opieki okołoporodowej sprawowanej nad kobietą w okresie fizjologicznej ciąży, fizjologicznego porodu, połogu oraz opieki nad noworodkiem. Dz.U. 2012 poz. 1100.
18. Najwyższa Izba Kontroli: Realizacja zadań Narodowego Funduszu Zdrowia w ramach planu finansowego na 2013 rok. NIK, Warszawa 2014.

19. Najwyższa Izba Kontroli: Informacja o wynikach kontroli opieki nad matką i noworodkiem w oddziałach położniczych i neonatologicznych. NIK, Poznań 2010.

20. World Health Organization: International Statistical Classification of Diseases and Related Health Problems: tenth revision. 2nd edition. Geneva 2004.

21. Luo ZC, Wilkins R. Degreeof rural isolation and birth outcomes. Paediatr Perinat Epidemiol.2008; 22(4): 341-349.

22. Strutz KL, Dozier AM, van Wijngaarden E, Glantz JC. Birth outcomes across three rural-urban typologies in the Finger Lakes region of New York. J Rural Health. 2012; 28(2): 162-173.

23. de Graaf JP, Ravelli AC, de Haan MA, Steegers EA, Bonsel GJ. Living in deprived urban districts increases perinatal health inequalities. J Matern Fetal Neonatal Med. 2013; 26(5): 473-481.

24. Smith LK, Budd JL, Field DJ, Draper ES. Socioeconomic inequalities in outcome of pregnancy and neonatal mortality associated with congenital anomalies: population based study. BMJ. 2011; 343: $\mathrm{d} 4306$. doi: $10.1136 /$ bmj.d4306.

25. Jurewicz J, Hanke W, Sobala W, Buczyńska A. Stosowane w Polsce środki ochrony roślin a ryzyko zaburzeń reprodukcji u osób pracujących w rolnictwie i w gospodarstwach ogrodniczych. Med Pr. 2004; 55(3): 275-281.

26. Langois $\mathrm{PH}$, Scheuerle A, Horel SA, Carozza SE. Urban versus rural residence and occurrence of septal heart defects in Texas. Birth Defects Res A Clin Mol Teratol. 2009; 85(9): 764-772.

27. Yang J, Carmichael SL, Canfield M, Song J, Shaw GM; National Birth Defects Prevention Study. Socioeconomic status in relation to selected birth defects in a large multicentered US case-control study. Am J Epidemiol. 2008; 167(2): 145-154.

28. Ministerstwo Zdrowia: Program kompleksowej diagnostyki i terapii wewnątrzmacicznej w profilaktyce następstw i powikłań wad rozwojowych i chorób płodu jako element poprawy stanu zdrowia płodów i noworodków na lata 2014-2017. MZ, Warszawa 2014.

29. Mayer ML, Slifkin RT, Skinner AC. The effect of rural residence and other social vulnerabilities on subjective measures of unmet need. Med Care Res Rev. 2005; 62(5): 617-628.

30. Kent ST, McClure LA, Zaitchik BF, Gohlke JM. Area-level risk factors for adverse birth outcomes: trends in urban and rural settings. BMC Pregnancy Childbirth. 2013; 13: 129. doi: 10.1186/1471-2393-13-129.

31. Varela MM, Nohr EA, Llopis-González A, Andersen AM, Olsen J. Socio-occupational status and congenital anomalies. Eur J Public Health. 2009; 19(2): 161-167.

32. Suliga E. Nutritional behaviors of pregnant women in rural and urban environments. Ann Agric Environ Med. 2015; 22(3): 513-517.

33. Pawłowska A, Filipp E, Pietrasik D, Krawczyńska M, Wilczyńska A, Niemiec KT. Analiza przebiegu ciąży oraz wyników położniczych u nastolatek rodzących w Klinice Położnictwa i Ginekologii Instytutu Matki i Dziecka w Warszawie. Gin Prakt. 2005; 84(4): 41-45.

34. Królikowska S. Sytuacja społeczna młodocianych matek. Rocz Socj Rodz. 2011; XXI: 79-101.

35. Poeran J, Maas AF, Birnie E, Denktas S, Steegers EA, Bonsel GJ. Social deprivation and adverse perinatal outcomes among Western and nonWestern pregnant women in a Dutch urban population. Soc Sci Med. 2013; 83: 42-49.

36. Żukiewicz-Sobczak W, Paprzycki P, Zwoliński J. Zachowania zdrowotne kobiet w ciąży. Lublin, Instytut Medycyny Wsi 2013.

37. César JA, Victora CG, Barros FC, Santos IS, Flores JA. Impact of breast feeding on admission for pneumonia during postneonatal period in Brazil: nested case-control study. BMJ. 1999; 318(7194): 1316-1320.

38. Singleton RJ, Wirsing EA, Haberling DL, Christensen KY, Paddock CD, Hilinski JA, et al. Risk factors for lower respiratory tract infection death among infants in the United States, 1999-2004. Pediatrics.2009; 124(4): e768-76. doi: 10.1542/peds.2009-0109.

39. Denktas S, Bonsel GJ, Van der Weg EJ, Voorham AJ, Torij HW, De Graaf JP, et al. An urban perinatal health program of strategies to improve perinatal health. Matern Child Health J. 2012; 16(8): 1553-1558.

40. Hollowell J, Kurinczuk JJ, Oakley L, Brocklehurst P, Gray R. A systematic review of the effectiveness of antenatal care programs to reduce infant mortality and its major causes in socially disadvantaged and vulnerable women. Final report. National Perinatal Epidemiology Unit, University of Oxford 2009. 